\title{
DETERMINATION OF CARBOXYLIC ACIDS CONTENT IN THE HERBAL MIXTURES BY HPLC
}

\author{
Alona Savych, Svitlana Marchyshyn, Roksolana Basaraba, Liubomyr Kryskiw
}

\begin{abstract}
The aim of the study was to research the qualitative composition and to investigate the quantitative content of some carboxylic acids in the herbal mixtures with established hypoglycemic, hypolipidemic and antioxidant activity in previous studies in vivo.

Materials and methods. Studies of carboxylic acid content in the herbal mixtures were performed by HPLC analysis using Agilent Technologies 1200 liquid chromatograph (USA). Identification and quantitative analysis were performed using standard solutions of carboxylic compounds (tartaric, pyruvic, isocitric, citric, succinic and fumaric acids).

Results. According to the results of chromatographic research it was found that the studied samples contain the largest amount of isocitric acid, the content of which was (45.22 \pm 0.04$) \mathrm{mg} / \mathrm{g}$ in the herbal mixture No. 3, (63.65 \pm 0.06$) \mathrm{mg} / \mathrm{g}$ in

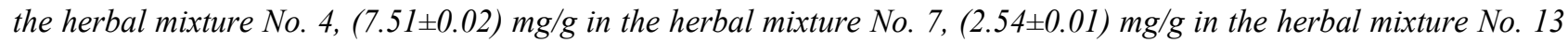
and (43.48 \pm 0.05$) \mathrm{mg} / \mathrm{g}$ in the herbal mixture No. 19. In addition, a high content of succinic acid which is an important regulator of mitochondrial dysfunction and fumaric acid which is a powerful immunomodulatory, anti-inflammatory and antioxidant agent was found.

Conclusions. HPLC analysis of five samples of the herbal mixture with antidiabetic activity showed the presence of six carboxylic acids. The dominant acid in all samples was isocitric acid. Among the most important for the prevention and treatment of diabetes, high levels of succinic and fumaric acids have been identified and established. The obtained data indicate a correlation between the phytochemical composition of the studied herbal mixtures and their pharmacodynamics, which was previously established
\end{abstract}

Keywords: herbal mixtures, carboxylic acids, high performance liquid chromatography, diabetes mellitus, phytotherapy, isocitric acid, succinic acid, fumaric acid

How to cite:

Savych, A., Marchyshyn, S., Basaraba, R., Kryskiw, L. (2021). Determination of carboxylic acids content in the herbal mixtures by HPLC. ScienceRise: Pharmaceutical Science, 2 (30), 33-39. doi: http://doi.org/10.15587/2519-4852.2021.229132

(C) The Author(s) 2021

This is an open access article under the Creative Commons CC BY license

\section{Introduction}

Diabetes mellitus is one of the priority problems of the WHO, which requires immediate solution, as the epidemiological situation is alarming - the number of patients is growing rapidly each year, leading to increased disability and mortality due to the development of macro- and microangiopathies [1,2]. According to the official data of the International Diabetes Federation (2019), the incidence of diabetes in the world is projected to increase 1.5 times by 2030 , amounting to more than 500 thousand patients [2]. Therefore, the optimization of existing antidiabetic pharmacotherapy, search and study of new drugs for the prevention and treatment of this disease and its complications is an important issue in modern pharmacy and medicine.

One of these areas is using phytomedicines in the form of monotherapy in the mild stages of the disease and for its prevention, and in combination with traditional therapy for more severe forms of the disease [3, 4]. Phytotherapy is a promising and reasonable method, as it has a number of advantages - relatively low toxicity of herbal medicines, mild pharmacological effect and the ability to use for a long time without significant side effects, the ability to combine well with synthetic drugs $[5,6]$. The combinations of different medicinal plants deserve particular attention. Herbal mixtures are expected to have several biologically active substances with a wide range of pharmacological actions and a variety of mechanisms for influencing the development of diabetes and diabetic angiopathies [7, 8].

Therefore, in order to establish correlations between the phytochemical composition of the studied herbal mixtures and its antidiabetic activity, which was studied in previous research $[9,10]$, it is advisable to conduct phytochemical analysis, in particular, carboxylic acids as one of the influential biologically active substances in the therapy of diabetes and its complications $[11,12]$.

Carboxylic acids are important phytochemicals that have a positive effect on the treatment and course of diabetes. This is especially true of succinic acid, which has the ability to increase insulin secretion by closing the channels $\mathrm{K}^{+}$-ATP, membrane depolarization and stimulating $\mathrm{Ca}^{2+}$ influx $[13,14]$. Fumaric acid and its 
esters exhibit immunomodulatory, anti-inflammatory and antioxidant activity, which are important pharmacodynamic parameters in the treatment of diabetes mellitus $[15,16]$.

Therefore, the aim of study was to investigate the content of carboxylic acids in some herbal mix- tures with previously studied antidiabetic activity in vivo $[9,10]$.

\section{Planning (methodology) of the research}

In Fig. 1 a graphical representation of the research planning process is shown.

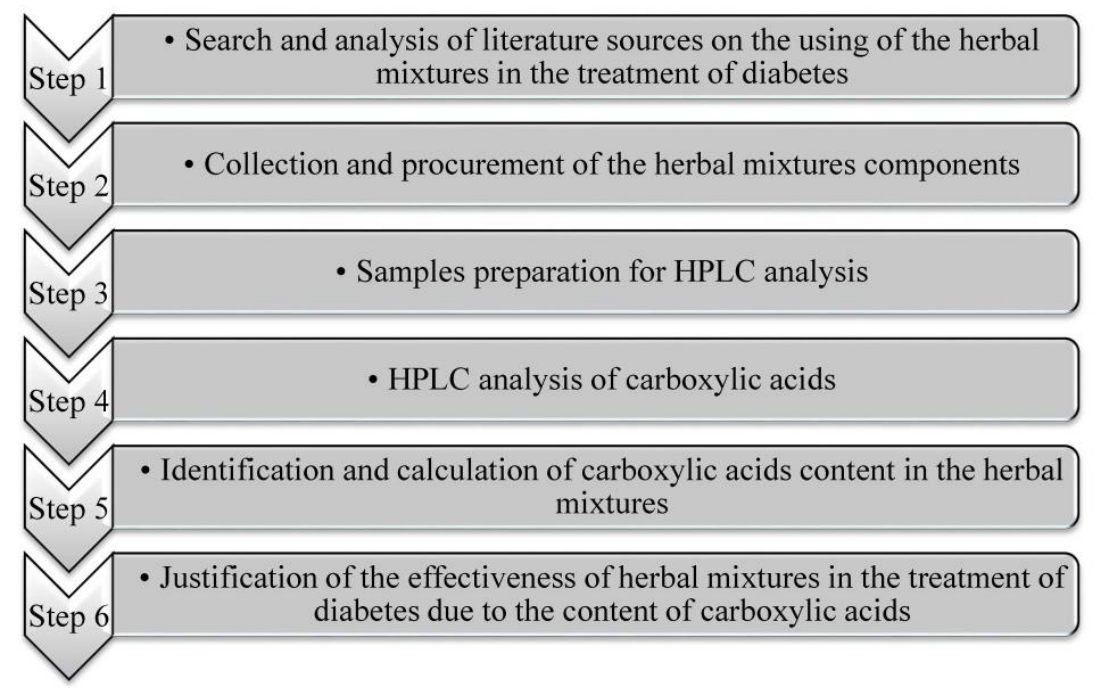

Fig. 1. Design of the experiment

\section{Materials and methods}

Plant materials: the herbal raw materials harvested from June to August 2019 in the Ternopil region (Ukraine) were used. After harvesting, the raw materials were dried, crushed and stored according to the general GACP requirements [17]. The plants were identified in the Department of Pharmacognosy with Medical Botany, Ternopil National Medical University named after I. Ya. Horbachevsky, Ternopil, Ukraine. The voucher specimens of herbal raw materials have been deposited in the departmental herbarium for future records. For the study, five different herbal mixtures with reliable antidiabetic activity established during pharmacological studies in vivo [9, 10] were used. The composition of the mixtures is given in Table 1.

Table 1

Composition of the herbal mixtures

\begin{tabular}{|c|c|c|c|}
\hline Herbal mixtures & Herbal drug component & Portion in the mixture, $\%$ & Relative ratio \\
\hline \multirow{5}{*}{ No. 3} & Urtica dioica leaf & 26.32 & 5 \\
\hline & Cichorium intybus roots & 26.32 & 5 \\
\hline & Rosa majalis fruits & 21.05 & 4 \\
\hline & Elymus repens rhizome & 15.79 & 3 \\
\hline & Taraxacum officinale roots & 10.52 & 2 \\
\hline \multirow{5}{*}{ No. 4} & Arctium lappa roots & 26.32 & 5 \\
\hline & Elymus repens rhizome & 26.32 & 5 \\
\hline & Zea mays columns with stigmas & 21.05 & 4 \\
\hline & Helichrysum arenarium flowers & 15.79 & 3 \\
\hline & Rosa majalis fruits & 10.52 & 2 \\
\hline \multirow{6}{*}{ No. 7} & Inula helenium rhizome with roots & 10.0 & 1 \\
\hline & Helichrysi arenarium flowers & 20.0 & 2 \\
\hline & Zea mays columns with stigmas & 20.0 & 2 \\
\hline & Origanum vulgari herb & 20.0 & 2 \\
\hline & Rosa majalis fruits & 20.0 & 2 \\
\hline & Taraxacum officinale roots & 10.0 & 1 \\
\hline \multirow{5}{*}{ No. 13} & Cichorium intybus roots & 26.32 & 5 \\
\hline & Elymus repens rhizome & 26.32 & 5 \\
\hline & Helichrysum arenarium flowers & 21.05 & 4 \\
\hline & Rosa majalis fruits & 15.79 & 3 \\
\hline & Zea mays columns with stigmas & 10.52 & 2 \\
\hline \multirow{5}{*}{ No. 19} & Urtica dioica leaf & 20.0 & 1 \\
\hline & Taraxacum officinale roots & 20.0 & 1 \\
\hline & Vaccinium myrtillus leaf & 20.0 & 1 \\
\hline & Rosa majalis fruits & 20.0 & 1 \\
\hline & Mentha piperita herb & 20.0 & 1 \\
\hline
\end{tabular}


Chemicals and standards: all applied reagents were of analytical grade ( $\geq 95 \%$ purity). Standards of organic acids, including tartaric acid, pyruvic acid, isocitric acid, citric acid, succinic acid and fumaric acid (Fig. 2) were purchased from Sigma-Aldrich
Chemical Company (St. Louis, MO, USA), as well as acetonitrile, undecanoic acid, methanol, heptane, toluene.

Water used in the studies was produced by MilliQ Gradient water deionizaton system (USA).

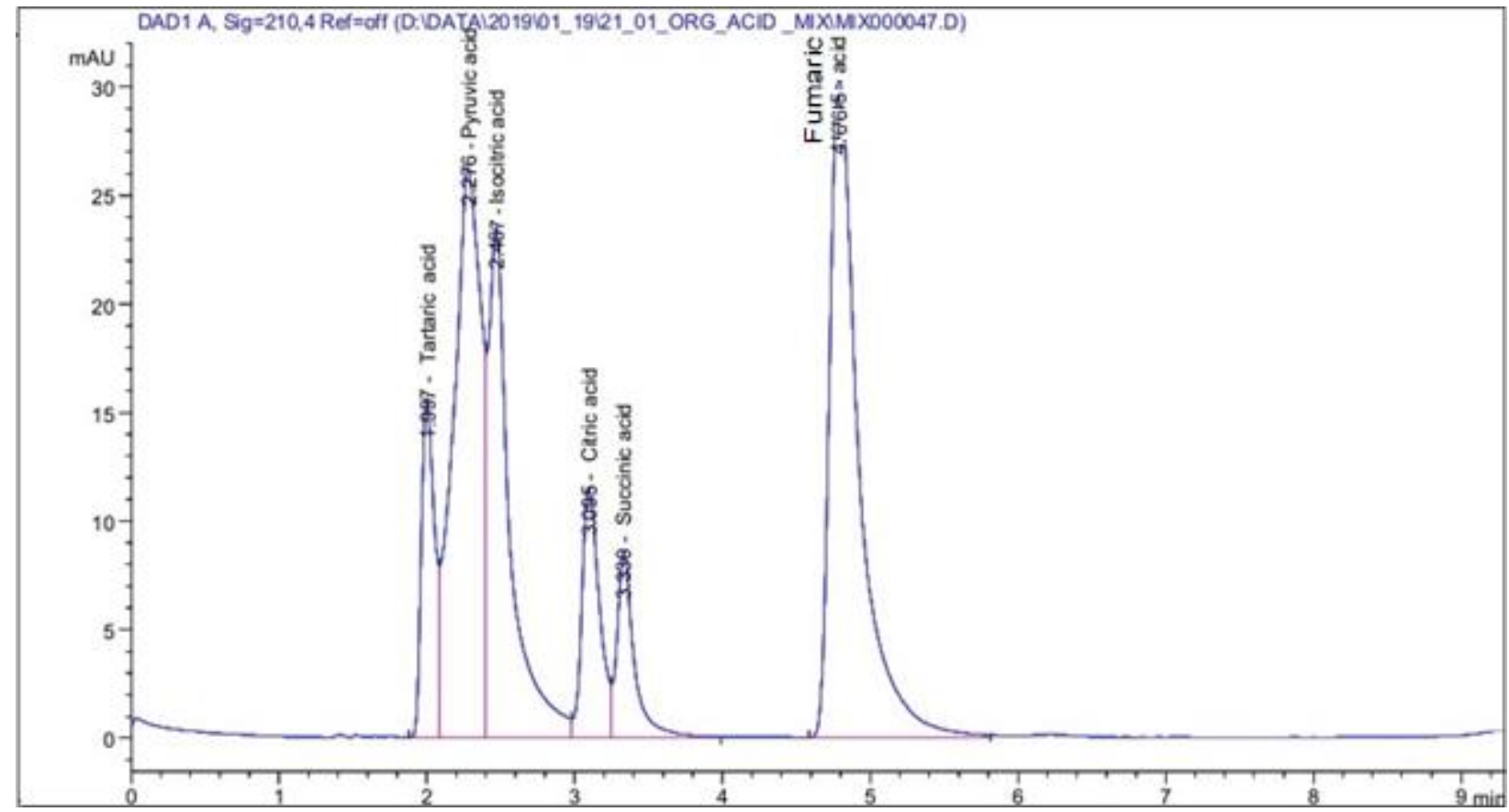

Fig. 2. HPLC chromatogram of a standard mixture of carboxylic acids

Instrumentation and conditions: HPLC analysis of carboxylic acids was performed using Agilent 1200 (Agilent Technologies, USA) [17, 18]. Mobile phase A acetonitrile $(\mathrm{ACN})$; mobile phase $\mathrm{B}-0.1 \%$ solution of phosphoric acid in water $(1: 99, \mathrm{v} / \mathrm{v})$. Elution was performed in isocratic mode. Separation was performed on a Zorbax SB-Aq chromatographic column $(4.6 \pm 150 \mathrm{~mm}$, $3.5 \mu \mathrm{m}$ ) (Agilent Technologies, USA), column flow rate $0.5 \mathrm{~mL} / \mathrm{min}$, the temperature of the thermostat column is $30{ }^{\circ} \mathrm{C}$, volume injection $3 \mu \mathrm{l}$. Detection was performed using a diode-matrix detector with signal registration at $210 \mathrm{~nm}$ and fixation of absorption spectra in the range of 210-700 nm.

Standard solutions (1000 ppm) of tartaric, pyruvic, isocitric, citric, succinic and fumaric acids were prepared in the mobile phase consisting of $0.1 \%$ phosphoric acid solution. Stock solutions of every carboxylic acid were made in the mobile phase by corresponding dilutions.

Extraction of carboxylic acids: $700 \mathrm{mg}$ of each powdered raw material was placed in a vial and extracted with $10 \mathrm{~mL}$ of $0.1 \%$ solution of phosphoric acid. Extraction was performed in the ultrasonic bath at $80{ }^{\circ} \mathrm{C}$ for 4 hours. Then $8.3 \mathrm{~mL}$ of the obtained extracts were centrifuged at $3000 \mathrm{rpm} / \mathrm{min}$ for 30 minutes and filtered through Supelco Discovery DSC-18 filter and then concentrated to the residual volume of the extract of $20 \mu \mathrm{l}$.

Identification and calculation by HPLC: was performed using standard solutions of carboxylic compounds (tartaric, pyruvic, isocitric, citric, succinic and fumaric acids). The content of organic acids in $\mu \mathrm{g} / \mathrm{g}$ was calculated by the following equation:

$$
X=\frac{C \times V_{s o l v} \times V_{i n j}}{m \times V_{\text {actual inj }} \times 1000},
$$

where C - concentration, obtained from the chromatogram by calculating the reference solution and the test solution;

$\mathrm{V}_{\text {solv }}$ - volume of solvent for extraction;

$\mathrm{V}_{\text {inj }}$ - volume of injection standard of organic acid;

$\mathrm{V}_{\text {actual inj }}$ - volume of injection of extract;

$\mathrm{m}-$ mass of the raw material.

\section{Result}

The results of qualitative and quantitative analyses of short chain carboxylic acids in the herbal mixtures are represented in Figs. 3-7 and in Table 2. 


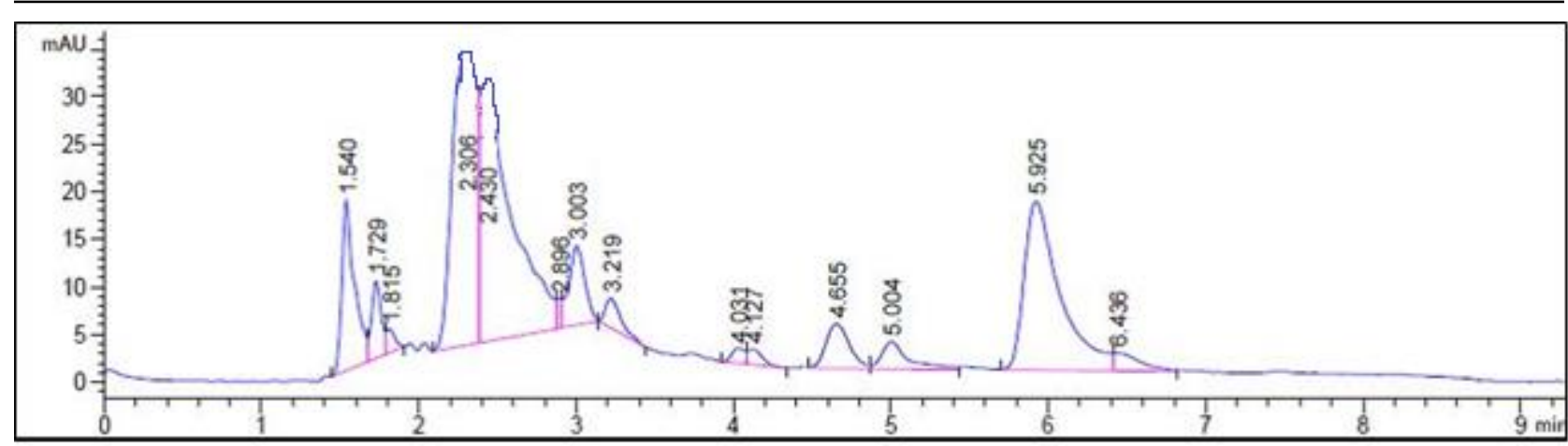

Fig. 3. HPLC chromatogram of carboxylic acids in the herbal mixture No. 3

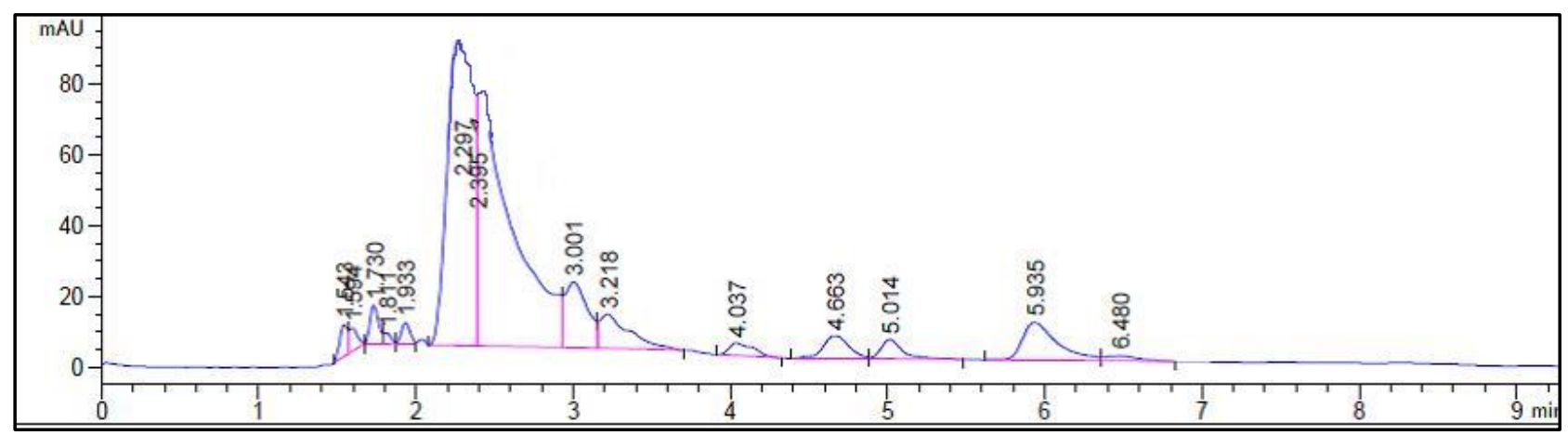

Fig. 4. HPLC chromatogram of carboxylic acids in the herbal mixture No. 4

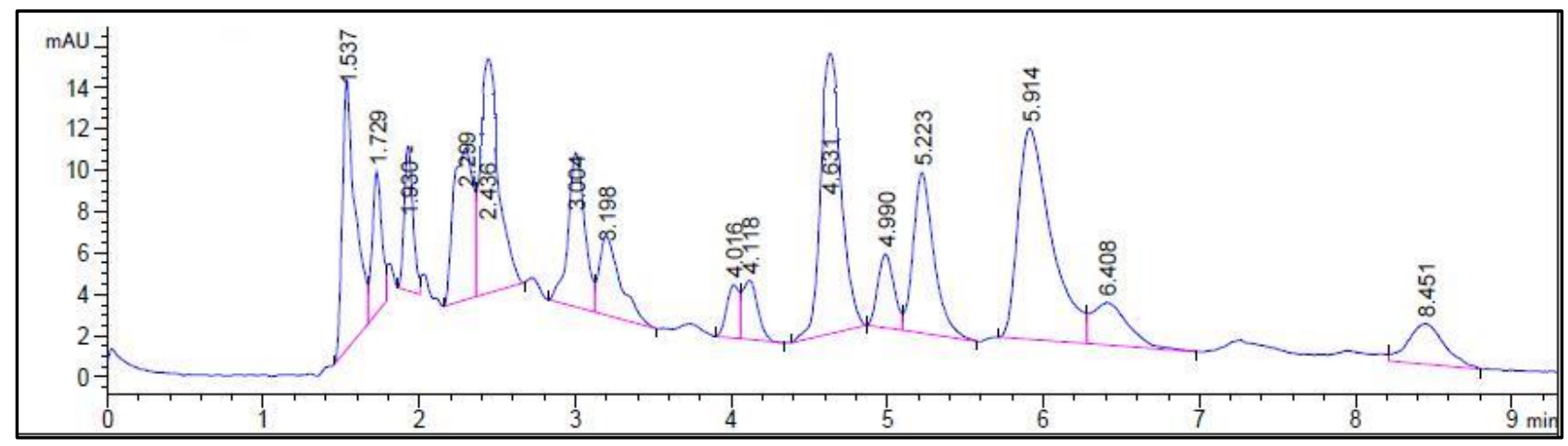

Fig. 5. HPLC chromatogram of carboxylic acids in the herbal mixture No. 7

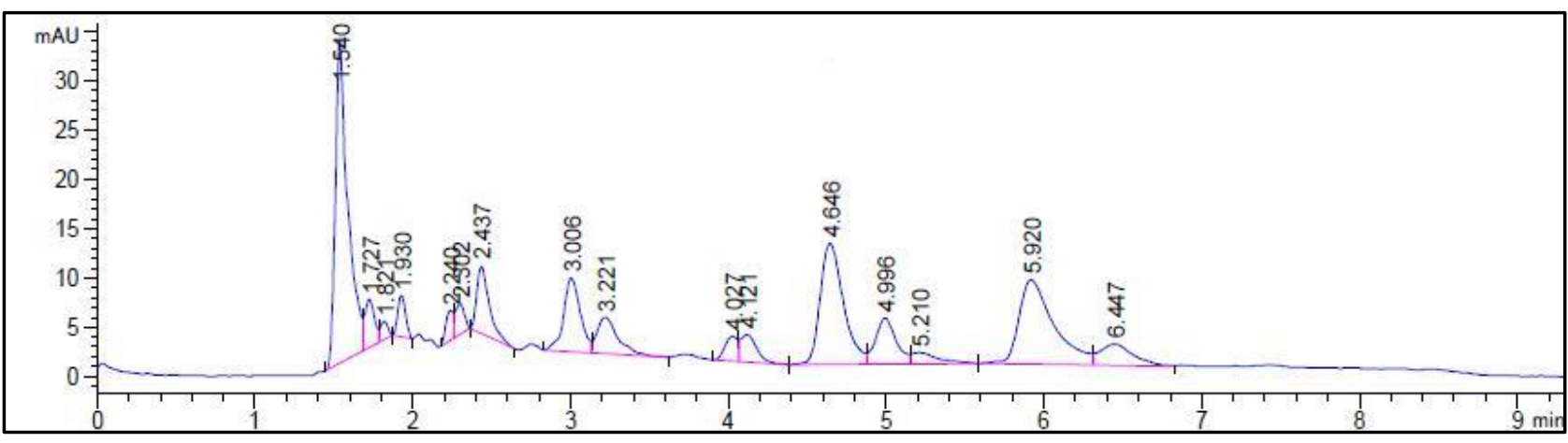

Fig. 6. HPLC chromatogram of carboxylic acids in the herbal mixture No. 13 


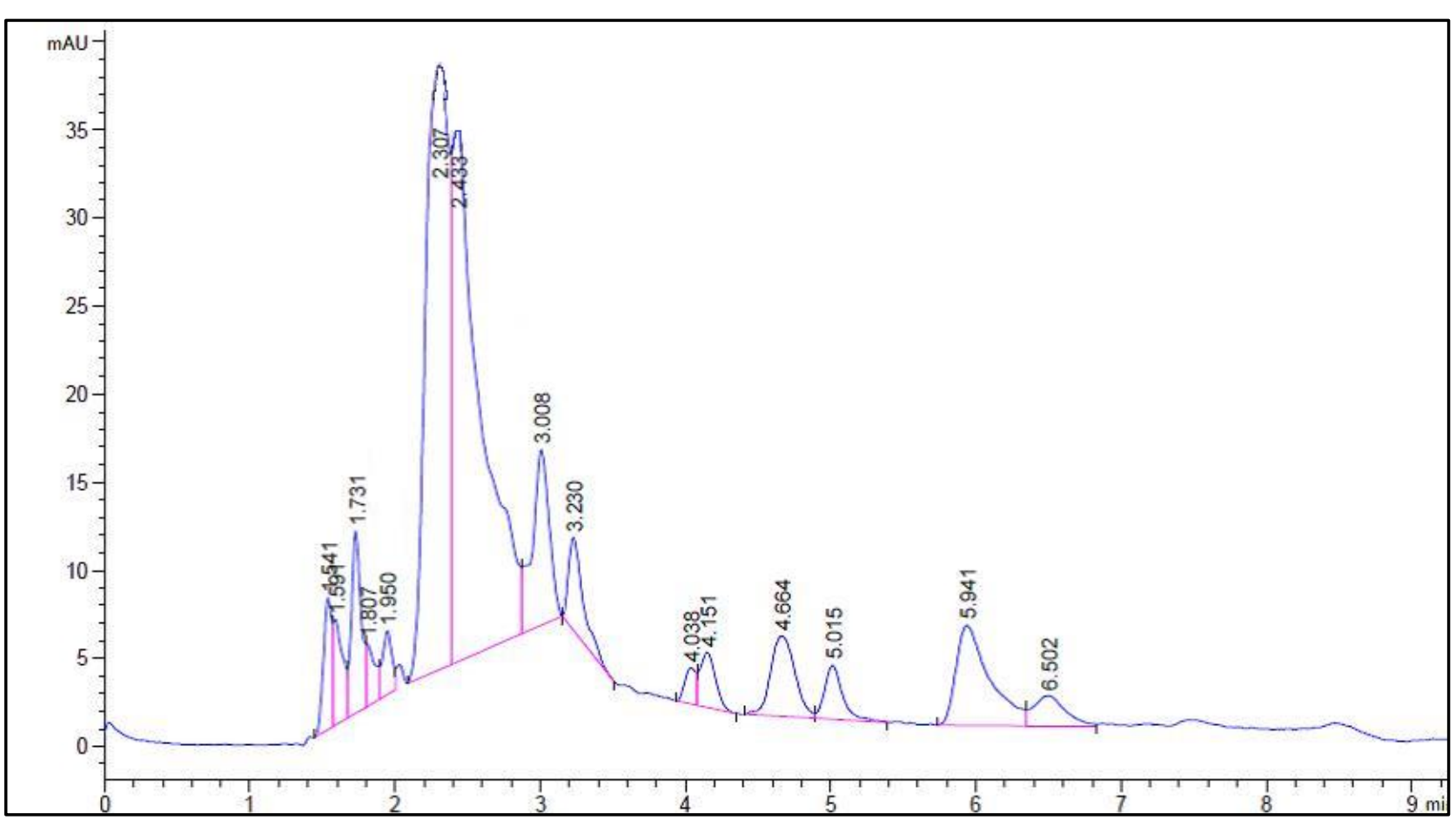

Fig. 7. HPLC chromatogram of carboxylic acids in the herbal mixture No. 19

Table 2

The results of the comparative analysis of carboxylic acids in the herbal mixtures

\begin{tabular}{|c|c|c|c|c|c|c|c|c|}
\hline \multirow{2}{*}{ No. } & \multirow{2}{*}{$\mathrm{tR}$} & \multirow{2}{*}{$\begin{array}{l}\text { Common name of carbox- } \\
\text { ylic acid (IUPAC) }\end{array}$} & \multirow{2}{*}{$\begin{array}{l}\text { Molecular } \\
\text { formula }\end{array}$} & \multicolumn{5}{|c|}{ Quantitative content the herbal mixtures, mg/g } \\
\hline & & & & No. 3 & No. 4 & No. 7 & No. 13 & No. 19 \\
\hline 1. & 1.930 & $\begin{array}{l}\text { Tartaric }(2,3- \\
\text { dihydroxybutanedioic) acid }\end{array}$ & C4H6O6 & $\mathrm{n} / \mathrm{d}$ & $0.45 \pm 0.02$ & $0.49 \pm 0.02$ & $0.29 \pm 0.01$ & $0.33 \pm 0.01$ \\
\hline 2. & 2.299 & $\begin{array}{l}\text { Pyruvic (2-oxopropanoic) } \\
\text { acid }\end{array}$ & $\mathrm{C} 3 \mathrm{H} 4 \mathrm{O} 3$ & $1.76 \pm 0.01$ & $4.62 \pm 0.03$ & $0.30 \pm 0.01$ & $0.08 \pm 0.01$ & $1.76 \pm 0.02$ \\
\hline 3. & 2.436 & $\begin{array}{l}\text { Isocitric (1- } \\
\text { hydroxypropane-1,2,3- } \\
\text { tricarboxylic) acid }\end{array}$ & С6H8O7 & $45.22 \pm 0.04$ & $63.65 \pm 0.06$ & $7.51 \pm 0.02$ & $2.54 \pm 0.01$ & $43.48 \pm 0.05$ \\
\hline 4. & 3.004 & $\begin{array}{l}\text { Citric (2-hydroxypropane- } \\
\text { 1,2,3-tricarboxylic) acid }\end{array}$ & C6H8O7 & $1.40 \pm 0.01$ & $3.52 \pm 0.03$ & $1.08 \pm 0.01$ & $1.17 \pm 0.01$ & $1.71 \pm 0.02$ \\
\hline 5. & 3.198 & Succinic (butanedioic) acid & $\mathrm{C} 4 \mathrm{H} 6 \mathrm{O} 4$ & $1.04 \pm 0.01$ & $4.60 \pm 0.03$ & $1.37 \pm 0.02$ & $1.38 \pm 0.01$ & $1.53 \pm 0.02$ \\
\hline 6. & 4.665 & $\begin{array}{l}\text { Fumaric ((2E)-but-2- } \\
\text { enedioic) acid }\end{array}$ & $\mathrm{C} 4 \mathrm{H} 4 \mathrm{O} 4$ & $0.06 \pm 0.01$ & $0.07 \pm 0.01$ & $0.10 \pm 0.01$ & $0.12 \pm 0.01$ & $0.06 \pm 0.01$ \\
\hline
\end{tabular}

Note: $1 . n / d-$ not detected; 2 . Values are expressed as mean $\pm S D(n=5)$

During HPLC analysis it was found that the herbal mixture No. 3 contains 5 components of carboxylic acids (pyruvic, isocitric, citric, succinic and fumaric acid), and the herbal mixtures No. 4, No. 7, No. 13 and No. $19-6$ components of carboxylic acids (tartaric, pyruvic, isocitric, citric, succinic and fumaric acid) (Figs. 3-7).

According to the results of chromatographic research it was found that in the studied herbal mixtures contain the largest amount of isocitric acid that was $(45.22 \pm 0.04) \mathrm{mg} / \mathrm{g}$ in the herbal mixture No. 3, $(63.65 \pm 0.06) \mathrm{mg} / \mathrm{g}$ in the herbal mixture No. 4, $(7.51 \pm 0.02) \mathrm{mg} / \mathrm{g}$ in the herbal mixture No. 7 , $(2.54 \pm 0.01) \mathrm{mg} / \mathrm{g}$ in the herbal mixture No. 13 and $(43.48 \pm 0.05) \mathrm{mg} / \mathrm{g}$ in the herbal mixture No. 19. In addition, a high content of succinic acid was found, which is an important regulator of mitochondrial dysfunction, $(1.04 \pm 0.01) \mathrm{mg} / \mathrm{g}$ in the herbal mixture No. 3,
$(4.60 \pm 0.03) \mathrm{mg} / \mathrm{g}$ in the herbal mixture No. 4, $(1.37 \pm 0.02) \mathrm{mg} / \mathrm{g}$ in the herbal mixture No. 7, (1.38 \pm 0.01$) \mathrm{mg} / \mathrm{g}$ in the herbal mixture No. 13 and $(1.53 \pm 0.02) \mathrm{mg} / \mathrm{g}$ in the herbal mixture No. 19. Regarding fumaric acid, which exhibits immunomodulatory, anti-inflammatory and antioxidant activity, its content in the studied plant samples was $-(0.06 \pm 0.01) \mathrm{mg} / \mathrm{g}$ in the herbal mixture No. 3, $(0.07 \pm 0.01) \mathrm{mg} / \mathrm{g}$ in the herbal mixture No. $4,(0.10 \pm 0.01) \mathrm{mg} / \mathrm{g}$ in the herbal mixture No. $7,(0.12 \pm 0.01) \mathrm{mg} / \mathrm{g}$ in the herbal mixture No. 13 and $(0.06 \pm 0.01) \mathrm{mg} / \mathrm{g}$ in the herbal mixture No. 19 (Figs. 37, Table 2).

\section{Discussion}

Carboxylic acids play an important role in the progression of diabetes and in the formation of diabetic angiopathies, in particular, succinic acid, which has the ability to reduce mitochondrial dysfunction that plays a 
leading role in the development of neurodegenerative diseases [21, 22]. In addition, succinic acid has an effect on the development of inflammation by reducing the neurotransmitters of inflammation [23, 24]. The high content of succinic acid found in the studied herbal mixtures may indicate the ability of these mixtures to prevent the development of mitochondrial dysfunction, and at the same time the development of oxidative stress, which is the main pathogenic mechanism of diabetic angiopathies. Fumaric acid has pronounced antioxidant properties, which is expressed by the cytoprotective ability against the harmful effects of lipid peroxidation and the development of oxidative stress, which underlie the development and progression of diabetic complications [24, 25]. Fumaric acid, which has been identified and quantified in all studied herbal mixtures, also has the ability to increase the function of the immune system and reduce inflammation [26, 27]. The obtained data testify to the expediency of using the studied herbal mixtures in order to optimize antidiabetic pharmacotherapy.

Study limitations. The research needs additional study of other carboxylic acids, as some acid compounds were not detected during the study.

Prospects for further research. According to the obtained research results, further screening of pharmaco- dynamic properties and development of parameters for standardization of plant mixtures is planned.

\section{Conclusions}

The results of chromatographic examination indicate a sufficient content of carboxilyc acids, in particular fumaric acid in five herbal mixtures, that has immunomodulatory, anti-inflammatory, antioxidant activity and succinic acid that has the ability to regulate mitochondrial dysfunction, which confirms the antidiabetic efficacy of five investigated samples in the pharmacological studies in vivo. The predominant carboxilyc acid was isocitric acid in all samples of the studied mixtures, its content was $(45.22 \pm 0.04) \mathrm{mg} / \mathrm{g}$ in the herbal mixture No. 3, $(63.65 \pm 0.06) \mathrm{mg} / \mathrm{g}$ in the herbal mixture No. 4, $(7.51 \pm 0.02) \mathrm{mg} / \mathrm{g}$ in the herbal mixture No. 7, $(2.54 \pm 0.01) \mathrm{mg} / \mathrm{g}$ in the herbal mixture No. 13 and $(43.48 \pm 0.05) \mathrm{mg} / \mathrm{g}$ in the herbal mixture No. 19. The obtained phytochemical studies may indicate a correlation between the component composition and content of carboxylic acid in the samples of studied mixtures and their effectiveness in the treatment and prevention of diabetes mellitus and its complications.

\section{Conflict of interests}

The authors declare that they have no conflicts of interest.

\section{References}

1. American Diabetes Association (2020). Standards of medical care in diabetes. Diabetes care, 43, 1212.

2. International Diabetes Federation. (2019). IDF Diabetes Atlas. Brussels. Available at: https://www.diabetesatlas.org

3. Governa, P., Baini, G., Borgonetti, V., Cettolin, G., Giachetti, D., Magnano, A. et. al. (2018). Phytotherapy in the Management of Diabetes: A Review. Molecules, 23 (1), 105. doi: http://doi.org/10.3390/molecules23010105

4. Kooti, W., Farokhipour, M., Asadzadeh, Z., Ashtary-Larky, D., Asadi-Samani, M. (2016). The role of medicinal plants in the treatment of diabetes: a systematic review. Electronic Physician, 8 (1), 1832-1842. doi: http://doi.org/10.19082/1832

5. Savych, A., Marchyshyn, S., Basaraba, R. (2020). Determination of fatty acid composition content in the herbal antidiabetic collections. Pharmacia, 67 (3), 153-159. doi: http://doi.org/10.3897/pharmacia.67.e51812

6. Savych, A., Marchyshyn, S., Kozyr, H., Yarema, N. (2021). Determination of inulin in the herbal mixtures by GC-MS method. Pharmacia, 68 (1), 181-187. doi: http://doi.org/10.3897/pharmacia.68.e55051

7. Savych, A., Marchyshyn, S., Harnyk, M., Kudria, V., Ocheretniuk, A. (2021). Determination of amino acids content in two samples of the plant mixtures by GC-MS. Pharmacia, 68 (1), 283-289. doi: http://doi.org/10.3897/pharmacia.68.e63453

8. Marchyshyn, S., Polonets, O., Savych, A., Nakonechna, S. (2020). Determination of carbohydrates of Chrysanthemum morifolium L. leaves and flowers by GC-MS. Pharmakeftiki Journal, 32 (4), 202-212.

9. Savych, A., Marchyshyn, M., Basaraba, R., Lukanyuk, M. (2020). Antihyperglycemic, hypolipidemic and antioxidant properties of the herbal mixtures in dexamethasone-induced insulin resistant rats. PharmacologyOnLine, 2, 73-82.

10. Savych, A., Marchyshyn, S., Basaraba, R. (2020). Screening study of hypoglycemic activity of the herbal mixtures (message 1). ScienceRise: Pharmaceutical Science, 4 (26), 40-46. doi: http://doi.org/10.15587/2519-4852.2020.210734

11. Ucar, F. B., Celik, G., Akpinar, O., Corbaci, C. (2014). Production of citric and isocitric acid by Yarrowia lipolytica strains grown on different carbon sources. Turkish Journal of Biochemistry, 39 (3), 285-290. doi: http://doi.org/10.5505/tjb. 2014.92005

12. Chi, Z., Wang, Z.-P., Wang, G.-Y., Khan, I., Chi, Z.-M. (2014). Microbial biosynthesis and secretion ofl-malic acid and its applications. Critical Reviews in Biotechnology, 36 (1), 99-107. doi: http://doi.org/10.3109/07388551.2014.924474

13. Ives, S. J., Zaleski, K. S., Slocum, C., Escudero, D., Sheridan, C., Legesse, S. et. al. (2020). The effect of succinic acid on the metabolic profile in high- fat diet- induced obesity and insulin resistance. Physiological Reports, 8 (21). doi: http://doi.org/10.14814/phy2.14630

14. Ferro, A., Carbone, E., Zhang, J., Marzouk, E., Villegas, M., Siegel, A. et. al. (2017). Short-term succinic acid treatment mitigates cerebellar mitochondrial OXPHOS dysfunction, neurodegeneration and ataxia in a Purkinje-specific spinocerebellar ataxia type 1 (SCA1) mouse model. PLOS ONE, 12 (12), e0188425. doi: http://doi.org/10.1371/journal.pone.0188425

15. Kronenberg, J., Pars, K., Brieskorn, M., Prajeeth, C., Heckers, S., Schwenkenbecher, P. et. al. (2019). Fumaric Acids Directly Influence Gene Expression of Neuroprotective Factors in Rodent Microglia. International Journal of Molecular Sciences, 20 (2), 325. doi: http://doi.org/10.3390/ijms20020325

16. Gill, A. J., Kolson, D. L. (2013). Dimethyl Fumarate Modulation of Immune and Antioxidant Responses: Application to HIV Therapy. Critical Reviews in Immunology, 33 (4), 307-359. doi: http://doi.org/10.1615/critrevimmunol.2013007247

17. WHO Guidelines on good agricultural and mixture practices (GACP) for medicinal plants (2003). World Health Organization Geneva, Switzerland, 72.

18. Agius, C., von Tucher, S., Poppenberger, B., Rozhon, W. (2018). Quantification of sugars and organic acids in tomato fruits. MethodsX, 5, 537-550. doi: http://doi.org/10.1016/j.mex.2018.05.014 
19. Ergönül, P. G., Nergiz, C. (2010). Determination of organic acids in olive fruit by HPLC. Czech Journal of Food Sciences, 28 (3), 202-205. doi: http://doi.org/10.17221/1379-cjfs

20. Beloborodova, N., Pautova, A., Sergeev, A., Fedotcheva, N. (2019). Serum Levels of Mitochondrial and Microbial Metabolites Reflect Mitochondrial Dysfunction in Different Stages of Sepsis. Metabolites, 9 (10), 196. doi: http://doi.org/10.3390/ metabo9100196

21. Lillefosse, H. H., Clausen, M. R., Yde, C. C., Ditlev, D. B., Zhang, X., Du, Z.-Y. et. al. (2014). Urinary Loss of Tricarboxylic Acid Cycle Intermediates As Revealed by Metabolomics Studies: An Underlying Mechanism to Reduce Lipid Accretion by Whey Protein Ingestion? Journal of Proteome Research, 13 (5), 2560-2570. doi: http://doi.org/10.1021/pr500039t

22. Gothai, S., Ganesan, P., Park, S.-Y., Fakurazi, S., Choi, D.-K., Arulselvan, P. (2016). Natural Phyto-Bioactive Compounds for the Treatment of Type 2 Diabetes: Inflammation as a Target. Nutrients, 8 (8), 461. doi: http://doi.org/10.3390/nu8080461

23. Chapela, S. P., Burgos, I., Congost, C., Canzonieri, R., Muryan, A., Alonso, M., Stella, C. A. (2018). Parenteral Succinate Reduces Systemic ROS Production in Septic Rats, but It Does Not Reduce Creatinine Levels. Oxidative Medicine and Cellular Longevity, 2018, 1-6. doi: http://doi.org/10.1155/2018/1928945

24. Dickel, H., Bruckner, T., Höxtermann, S., Dickel, B., Trinder, E., Altmeyer, P. (2019). Fumaric acid ester- induced Tcell lymphopenia in the real- life treatment of psoriasis. Journal of the European Academy of Dermatology and Venereology, 33 (5), 893-905. doi: http://doi.org/10.1111/jdv.15448

25. Li, S., Vaziri, N. D., Swentek, L., Takasu, C., Vo, K., Stamos, M. J. et. al. (2021). Prevention of Autoimmune Diabetes in NOD Mice by Dimethyl Fumarate. Antioxidants, 10 (2), 193. doi: http://doi.org/10.3390/antiox10020193

26. Adam, J., Ramracheya, R., Chibalina, M. V., Ternette, N., Hamilton, A., Tarasov, A. I. et. al. (2017). Fumarate Hydratase Deletion in Pancreatic $\beta$ Cells Leads to Progressive Diabetes. Cell Reports, 20 (13), 3135-3148. doi: http://doi.org/10.1016/j. celrep.2017.08.093

27. Dickel, H., Bruckner, T., Altmeyer, P. (2018). Long-term real-life safety profile and effectiveness of fumaric acid esters in psoriasis patients: a single-centre, retrospective, observational study. Journal of the European Academy of Dermatology and Venereology, 32 (10), 1710-1727. doi: http://doi.org/10.1111/jdv.15019

Received date 05.03.2021

Accepted date 09.04.2021

Published date 30.04.2021

Alona Savych, PhD, Associate Professor, Department of Pharnacognosy with Medical Botany, I. Horbachevsky Ternopil National Medical University of Ministry of Health of Ukraine, Voli sq., 1, Ternopil, Ukraine, 46001 E-mail: alonasavych@gmail.com

Svitlana Marchyshyn, Doctor of Pharmaceutical Science, Professor, Department of Pharnacognosy with Medical Botany, I. Horbachevsky Ternopil National Medical University of Ministry of Health of Ukraine, Voli sq., 1, Ternopil, Ukraine, 46001

E-mail: svitlanafarm@ukr.net

Roksolana Basaraba, PhD, Assistant, Department of Pharmacy, Bukovinian State Medical University, Teatralna str., 2, Chernivtsi, Ukraine, 58002

E-mail: roksishka1@gmail.com

Liubomyr Kryskiw, PhD, Senior Lecturer, Department of Pharmaceutical Chemistry, I. Horbachevsky Ternopil National Medical University of Ministry of Health of Ukraine, Voli sq., 1, Ternopil, Ukraine, 46001

E-mail: lub.s.kryskiw@gmail.com 